\title{
Method for the production of antibacterial peptides from biological fluids at an ionic membrane. Application to the isolation of nisin and caprine lactoferricin
}

\author{
Isidra Recio, Charles J. Slangen, Servaas VISSER* \\ Department of Product Technology, NIZO food research, \\ P.O. Box 20, 6710 BA Ede, The Netherlands
}

\begin{abstract}
Cationic peptides could be successfully released from a precursor protein bound to a cation-exchange membrane by in-situ enzymatic cleavage with an appropriate enzyme. This procedure allows the washing-off of other hydrolytic fragments from the membrane before the selective removal of the strongly bound target peptide(s) at increased $\mathrm{pH}$ or with high ionic strength buffer. Two new applications of this method are presented. The lantibiotic nisin could be released with high efficiency by tryptic hydrolysis of its precursor polypeptide bound to the ionic membrane. Further, the production of a fraction enriched in a novel antibacterial domain from the $\mathrm{N}$-terminal part of caprine lactoferrin is reported. Characterisation of this domain by mass spectrometry and $\mathrm{N}$-terminal sequence analysis revealed that this peptide corresponded to fragment 14-42 of the sequence of mature caprine lactoferrin, here referred to as lactoferricin-C. Thus, the purification procedure shown can be used to isolate cationic peptides initially produced in a longer, inactive form by bacteria (fusion proteins) or naturally occurring antibacterial peptides generated by the digestion of proteins.
\end{abstract}

antibacterial cationic peptide / membrane cation-exchange chromatography / hydrolysis of membrane-bound protein / nisin / caprine lactoferricin

\section{INTRODUCTION}

In the past few years, antimicrobial peptides have been isolated from a variety of natural sources $[2,5]$. A number of endogenous antimicrobial peptides of plants and animals were found to be cationic, amphiphilic molecules composed of 12 to 45 amino acid residues. In addition to naturally occurring peptides, antimicrobial peptides which arise from the in-vitro digestion of larger proteins have been reported, for

\footnotetext{
* Correspondence and reprints. SVISSER@ nizo.nl
} 
instance by using bactericidal/permeability-increasing protein [11], or tenecin 1 [9] as starting material.

Several cationic antibacterial peptides have been made by enzymatic hydrolysis of milk proteins, such as the minor whey protein lactoferrin (LF) $[1,4,6,12]$. The most active LF-derived fragment, named lactoferricin-B [1], has more potent bactericidal effect than undigested LF, suggesting that its much smaller size facilitates access to target sites on the microbial surface [15]. Recently, we have reported two cationic antibacterial peptides prepared from bovine $\alpha_{\mathrm{s} 2}$-casein hydrolysed with pepsin [13].

One potential limitation for the useful application of antimicrobial peptides is the cost of production. Peptides derived from longer proteins can be produced in vitro by enzymatic hydrolysis of the precursor protein, but the procedure is expensive and labour-intensive since it comprises, first, the purification of the precursor protein and, in a second step, the isolation of the active peptide from a, generally complex, hydrolysate. For naturally occurring peptides, production from natural sources is, in general, not cost-effective and automated chemical procedures, such as solid-phase synthesis, would also be too expensive, except for very short peptides [2]. An alternative strategy is the production of cationic antibacterial peptides as fusion proteins in bacteria. By this procedure, the cationic peptide is produced in a longer, inactive form (normally with an extra anionic segment) to stabilise the cationic segment and to prevent both antibiotic activity against the host bacterium and proteolysis during recombinant-protein production [5].

Therefore, it is important to develop costeffective production methods for cationic peptides starting from polypeptides or proteins which may be present in complex mixtures. In a previous paper [12], we have described a method for the production of lactoferricin-B starting from bovine cheese whey. This method includes the concentration of the precursor protein on an ion- exchange chromatographic membrane and the in-situ enzymatic hydrolysis of the membrane-bound protein. This procedure has been also successfully applied to the isolation of an antibacterial domain within the sequence of $\alpha_{\mathrm{s} 2}$-casein [13]. In the present paper, we report two new applications. By using this method, the lantibiotic nisin A could be purified from a cell culture of a strain producing nisin precursor. The isolation of an antibacterial domain within the sequence of caprine LF from cheese whey was also achieved with this method.

\section{MATERIALS AND METHODS}

\subsection{Materials}

For the production of nisin A and its precursor, Lactococcus lactis strains NZ9700 [7] and MG1614 harbouring the plasmid pNZ9111 [14], respectively, were used (NIZO collection). The latter strain produces and secretes nisin exclusively in its precursor form, which is the final intermediate in the biosynthesis of this lantibiotic and does not show antibacterial activity under the conditions used in this study. For nisin A production, L. lactis NZ9700 was grown to the stationary phase without aeration at $30{ }^{\circ} \mathrm{C}$ in M17 broth (Difco Laboratories, Detroit, MI, USA) supplemented with $0.5 \mathrm{w} / \mathrm{v} \%$ sucrose (final optical density at $600 \mathrm{~nm}$ 1.7-1.8, $\mathrm{pH} 4.8$ ). For the production of the nisin A precursor, L. lactis MG1614 carrying pNZ9111 was cultivated to the early stationary phase in M17 broth supplemented with $0.5 \mathrm{w} / \mathrm{v} \%$ glucose and $10 \mu \mathrm{g} \cdot \mathrm{mL}^{-1}$ erythromycin (EGM17) (final optical density at $600 \mathrm{~nm} 0.9-1.0, \mathrm{pH} 6.2$ ). Cultures were centrifuged for $20 \mathrm{~min}$ at $2500 \mathrm{~g}$ to remove lactococcal cells. The supernatant was again centrifuged for $30 \mathrm{~min}$ at $10.000 \cdot \mathrm{g}$ and, after dilution with bidistilled water, the $\mathrm{pH}$ was adjusted to 4.5-4.8 with acetic acid.

Caprine cheese whey ( $\mathrm{pH}$ 6.5) was obtained from a local farm. To avoid 
membrane clogging, it was microfiltered prior to the membrane ion-exchange procedure.

Porcine pepsin A (E.C. 3.4.23.1., 445 units. $\mathrm{mg}^{-1}$ solid) and trypsin from bovine pan-

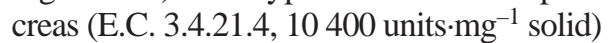
were from Sigma Chemical Co. (SaintLouis, MO, USA).

\subsection{Enzymatic hydrolysis of the protein bound to an ion-exchange membrane}

Experiments were carried out with a Sartorius Sartobind S cation-exchange membrane in an MA 100 configuration $\left(100 \mathrm{~cm}^{2}\right.$ adsorption area) (Sartorius, Göttingen, Germany). Binding and recovery of protein material were investigated at room temperature $\left(25^{\circ} \mathrm{C}\right)$ using a flow rate of $20 \mathrm{~mL} \cdot \mathrm{min}^{-1}$, which was generated by a peristaltic pump (Verder-Vleuten b.v., Vleuten, The Netherlands). The process was monitored by a UV detector with a 2-mm lightpath flow cuvette (model EM-1 Econo UV Monitor, Bio-Rad Laboratories, Richmond, CA, USA) at $280 \mathrm{~nm}$.

Prior to use, the cation-exchange membrane was equilibrated with a low ionic strength buffer at the $\mathrm{pH}$ selected for the protein binding. This buffer $\mathrm{pH}$ was chosen to be at least 1 unit below the isoelectric point of the protein. Thus, membrane equilibration was achieved with $10 \mathrm{mmol} \cdot \mathrm{L}^{-1}$ sodium phosphate buffer, $\mathrm{pH}$ 7.0, for caprine $\mathrm{LF}$ and with $10 \mathrm{mmol} \cdot \mathrm{L}^{-1}$ ammonium acetate buffer, $\mathrm{pH} 4.5$, for nisin precursor.

The solution containing the precursor protein or peptide (i.e. cheese whey or fermentation medium) was pumped at $20 \mathrm{~mL} \cdot \mathrm{min}^{-1}$ and at room temperature through the membrane, which was followed by a washing with a low ionic strength buffer at the $\mathrm{pH}$ of the desired enzymatic hydrolysis reaction (HCl-acidified water, $\mathrm{pH} 3.0$, before hydrolysis with pepsin or $10 \mathrm{mmol} \cdot \mathrm{L}^{-1}$ phosphate buffer, $\mathrm{pH} 7.0$, before hydrolysis with trypsin).
The membrane-bound protein was hydrolysed at $37^{\circ} \mathrm{C}$ by recycling at $20 \mathrm{~mL}$. $\mathrm{min}^{-1}$ (at reverse flow, to remove air bubbles) a solution containing the appropriate enzyme. An aqueous solution $(100 \mathrm{~mL}, \mathrm{pH}$ 3.0) of porcine pepsin $\left(25 \mathrm{mg} \cdot \mathrm{mL}^{-1}\right)$ was used to hydrolyse caprine LF for a period between $4 \mathrm{~h}$ and overnight. Nisin precursor was hydrolysed by using a $50 \mathrm{~mL}$-solution of trypsin $\left(0.1 \mathrm{mg} \cdot \mathrm{mL}^{-1}\right)$ in $10 \mathrm{mmol} \cdot \mathrm{L}^{-1}$ sodium phosphate buffer, $\mathrm{pH} 7.0$, for a period between $15 \mathrm{~min}$ and $3 \mathrm{~h}$. After hydrolysis, the membrane was washed sequentially with buffers of increasing $\mathrm{pH}$ or increasing ionic strength. The remaining, strongly bound peptides were eluted with $1 \mathrm{~mol} \cdot \mathrm{L}^{-1} \mathrm{NaCl}$ or $1 \mathrm{~mol} \cdot \mathrm{L}^{-1} \mathrm{KCl}$ in phosphate buffer $\mathrm{pH}$ 7.0. All fractions were collected, tested for activity and analysed by analytical reversed-phase high-performance liquid chromatography (RP-HPLC). Since the antibacterial activity of LF fragments may be diminished in the presence of salts [16], the $\mathrm{NaCl}$ fractions from the peptic hydrolysate of caprine LF were desalted by using a Sep-Pak $\mathrm{C}_{18}$ cartridge (Waters, Milford, MA, USA) [12].

The cation-exchange membrane was regenerated with $0.2 \mathrm{~mol} \cdot \mathrm{L}^{-1}$ or $1 \mathrm{~mol} \cdot \mathrm{L}^{-1}$ $\mathrm{NaOH}$ followed by $1 \mathrm{~mol} \cdot \mathrm{L}^{-1} \mathrm{HCl}$ before further use.

\subsection{Analytical and preparative RP-HPLC}

The RP-HPLC analysis of fractions collected after hydrolysis of caprine LF was carried out by using a $250 \times 4.6 \mathrm{~mm}$ Widepore $\mathrm{C}_{18}$ column (Bio-Rad), as described previously [12]. Fractions of nisin or nisin precursor were analysed by the same procedure, but peptides were eluted with a linear gradient of solvent B in A going from $10 \%$ to $25 \%$ in $10 \mathrm{~min}$ followed by a 50 -min linear gradient from 25 to $30 \%$ of solvent $\mathrm{B}$ in solvent $\mathrm{A}$ at a flow rate of $0.8 \mathrm{~mL} \cdot \mathrm{min}^{-1}$. Solvent A was a mixture of acetonitrile-water-trifluoroacetic acid (100:900:1, v/v/v) and solvent B contained 
the same components (900:100:0.8, v/v/v). For mass spectrometry (MS) analysis (see 2.4), peptides were manually collected from the analytical HPLC system in 1-mL Eppendorf tubes, freeze-dried and kept at $-20^{\circ} \mathrm{C}$.

To collect pure material for the antibacterial assay (see 2.5) and the N-terminal sequence analysis, the antibacterial fraction obtained after hydrolysis of bound caprine LF was further purified by preparative RP-HPLC under conditions described previously [12].

\subsection{Identification of peptides}

Identification of the antibacterial domain of caprine LF was achieved by combining $\mathrm{N}$-terminal sequence and molecular mass data of the peptide, and matching these to the known amino-acid sequence of caprine LF [8]. Nisin A and nisin A precursor were identified by RP-HPLC using reference material prepared at NIZO food research and by the mass spectrometric data of these peptides.

MS spectra were recorded using a Quattro II triple quadrupole mass spectrometer (Micromass, Cheshire, UK) as described previously [12].

The N-terminal sequence of the purified fragment of caprine LF was identified by sequence analysis with a gas-phase sequenator (Model 470A, Applied Biosystems, Foster City, CA, USA) under the conditions described [12].

\subsection{Assay for antibacterial activity}

Antibacterial activities of the fractions collected from the ion-exchange membrane and of purified peptides were determined by a plate diffusion assay against Micrococcus flavus DSM 1790 [12]. Fractions from LF hydrolysates were tested at concentrations ranging from 0.2 to $30 \mathrm{mg} \cdot \mathrm{mL}^{-1}$. Nisin and nisin precursor were tested at concentrations lower than $10 \mu \mathrm{g} \cdot \mathrm{mL}^{-1}$.

\section{RESULTS AND DISCUSSION}

\subsection{Isolation of nisin produced by Lactococcus lactis as nisin precursor}

Because proteins and peptides present in a rich medium like M17 may complicate the concentration of nisin precursor on the chromatographic membrane, in a preliminary experiment the breakthrough curve and recovery of nisin were measured using 0 , 2, 5 and 10-fold aqueous dilutions of the cell-free extract (CFE) ( $\mathrm{pH} 4.5)$. Although the adsorption/elution behaviour of nisin and nisin precursor at the membrane may be different, for these experiments a CFE containing nisin was used, because the detection limit of nisin by the bioassay agar activity test is much lower than the detection limit of nisin precursor by RP-HPLC (about $0.1 \mu \mathrm{g} \cdot \mathrm{mL}^{-1}$ and $3.2 \mu \mathrm{g} \cdot \mathrm{mL}^{-1}$, respectively). The highest recovery of nisin in the $1 \mathrm{~mol} \cdot \mathrm{L}^{-1}$ $\mathrm{NaCl}$ fraction was obtained when a 10-fold diluted CFE was used as feeding solution.

For the binding and recovery study with nisin precursor a 10 -fold diluted $\mathrm{CFE}$ was therefore used and $1 \mathrm{~mol} \cdot \mathrm{L}^{-1} \mathrm{NaCl}$ or $1 \mathrm{~mol} \cdot \mathrm{L}^{-1} \mathrm{KCl}$ in phosphate buffer $(\mathrm{pH} 7.0)$ was used for elution, followed by $0.2 \mathrm{~mol} \cdot \mathrm{L}^{-1}$ $\mathrm{NaOH}$ to regenerate the membrane. After $6 \mathrm{~h}$ of growth of a $1 \%$ inoculum of precursor-producing L. lactis in EGM17, the undiluted CFE contained $7.3 \pm 0.5 \mu \mathrm{g} \cdot \mathrm{mL}^{-1}$ $(n=3)$ of nisin precursor, as determined by RP-HPLC. To determine the binding and recovery, $100 \mathrm{~mL}$ of 10 -fold diluted CFE was loaded onto the membrane and the breakthrough effluent, the peaks eluted with $1 \mathrm{~mol} \cdot \mathrm{L}^{-1} \mathrm{KCl}$ or $1 \mathrm{~mol} \cdot \mathrm{L}^{-1} \mathrm{NaCl}$ and the regenerating solution $\left(0.2 \mathrm{~mol} \cdot \mathrm{L}^{-1} \mathrm{NaOH}\right)$ were analysed by RP-HPLC. The nisin precursor was exclusively recovered in the $\mathrm{KCl}$ or $\mathrm{NaCl}$-containing fraction and equal amounts of nisin precursor were found when using either $\mathrm{KCl}$ or $\mathrm{NaCl}$ (data not shown). In a separate experiment, three different volumes of 10-fold diluted CFE were loaded onto the membrane and the amount of nisin 


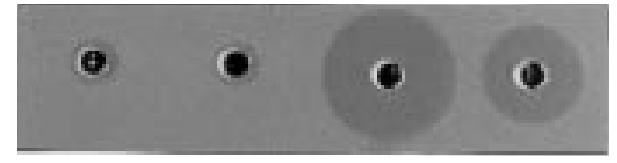

$\begin{array}{llll}a & b & c & d\end{array}$

Figure 1. Agar diffusion assay using M. flavus as indicator microorganism. Inhibition zones were obtained by spotting the fractions collected from the cation-exchange membrane after hydrolysis of nisin A precursor on the membrane for $15 \mathrm{~min}$ with trypsin: (a) the $10 \mathrm{mmol} \cdot \mathrm{L}^{-1}$ sodium phosphate fraction, (b) the solution of trypsin removed immediately after the hydrolysis, (c) the $1 \mathrm{~mol} \cdot \mathrm{L}^{-1} \mathrm{KCl}$ fraction, (d) the $0.2 \mathrm{~mol} \cdot \mathrm{L}^{-1}$ $\mathrm{NaOH}$ fraction.

precursor in the $\mathrm{KCl}$ fraction was quantified by RP-HPLC. A loading volume of $1 \mathrm{~L}$ of diluted CFE yielded $362 \pm 6 \mu \mathrm{g}$ of nisin precursor (54\% recovery) in the $\mathrm{KCl}$ fraction, whereas loading volumes of $2 \mathrm{~L}$ and $3 \mathrm{~L}$ resulted in $598 \pm 6 \mu \mathrm{g}(41 \%)$ and $783 \pm$ $6 \mu \mathrm{g}(36 \%)$, respectively $(n=3)$. A similar effect of the loading volume on the recovery of bovine LF from cheese whey was observed earlier using this type of ionic membrane [3].

After passing $3 \mathrm{~L}$ of 10 -fold diluted CFE, the nisin precursor was at least 540 -fold concentrated within the cation-exchange membrane ( $2 \mathrm{~mL}$ of membrane volume) with respect to the concentration of nisin precursor in the feeding solution. After washing the membrane with phosphate buffer to remove unbound material and hydrolysing the nisin precursor bound to the membrane with trypsin at $\mathrm{pH} 7.0$ for different times, all washing solutions, including the $0.2 \mathrm{~mol} \cdot \mathrm{L}^{-1} \mathrm{NaOH}$ solution used for membrane regeneration, were tested for activity against $M$. flavus. No activity was found in the trypsin solution removed after hydrolysis (Fig. 1b) and a negligible halo could be detected in the phosphate buffer fraction used to wash the membrane before elution with $\mathrm{KCl}$ (Fig. 1a). Most of the activity was recovered in the $\mathrm{KCl}$-containing fraction after hydrolysis (Fig. 1c), although some activity was also found in the $0.2 \mathrm{~mol} \cdot \mathrm{L}^{-1} \mathrm{NaOH}$ fraction (Fig. 1d). These two active fractions were analysed by RPHPLC. After 15 min of hydrolysis, the HPLC peak corresponding to nisin precursor was absent in the $\mathrm{KCl}$ fraction, but this fraction contained $288 \pm 11 \mu \mathrm{g}(n=2)$ of nisin as determined by RP-HPLC (Fig. 2c). The solution of $\mathrm{NaOH}$ used for regeneration of the membrane contained also a small amount of nisin $(57 \pm 11 \mu \mathrm{g})$ not recovered in the $\mathrm{KCl}$ fraction and this explains the antibacterial activity observed in this fraction (Fig. 1d). The small amounts of other components in the $\mathrm{KCl}$ fraction (Fig. 2c) precluded further identification of these peptides by MS.

\subsection{Isolation of an antibacterial domain of caprine $L F$ from cheese whey}

In a preliminary experiment we found that a peptic hydrolysate of caprine LF had antibacterial properties similar to those observed with bovine LF hydrolysed with pepsin. Further, sequence-homology analysis revealed high identity at the amino acid level between caprine and bovine LFs (92\%) [8]. In a previous paper [12], we reported the hydrolysis of bovine LF bound to the ion-exchange membrane and the isolation of the bactericidal domain of LF, lactoferricin-B. The same procedure was followed to generate and isolate an antibacterial peptide from caprine LF.

Approximately $1 \mathrm{~L}$ of microfiltered caprine cheese whey was passed through the membrane. By using this loading volume, the bound fraction, when eluted with $1 \mathrm{~mol} \cdot \mathrm{L}^{-1} \mathrm{NaCl}$, consisted of $\mathrm{LF}$ and a smaller amount of lactoperoxidase $(43 \%$ expressed as percentage of the peak area of LF), as determined by RP-HPLC. After prewashing the protein-loaded membrane with acidified water ( $\mathrm{pH}$ 3.0) to remove unbound material and to bring the membrane to the desired $\mathrm{pH}$ for the hydrolysis with pepsin, 


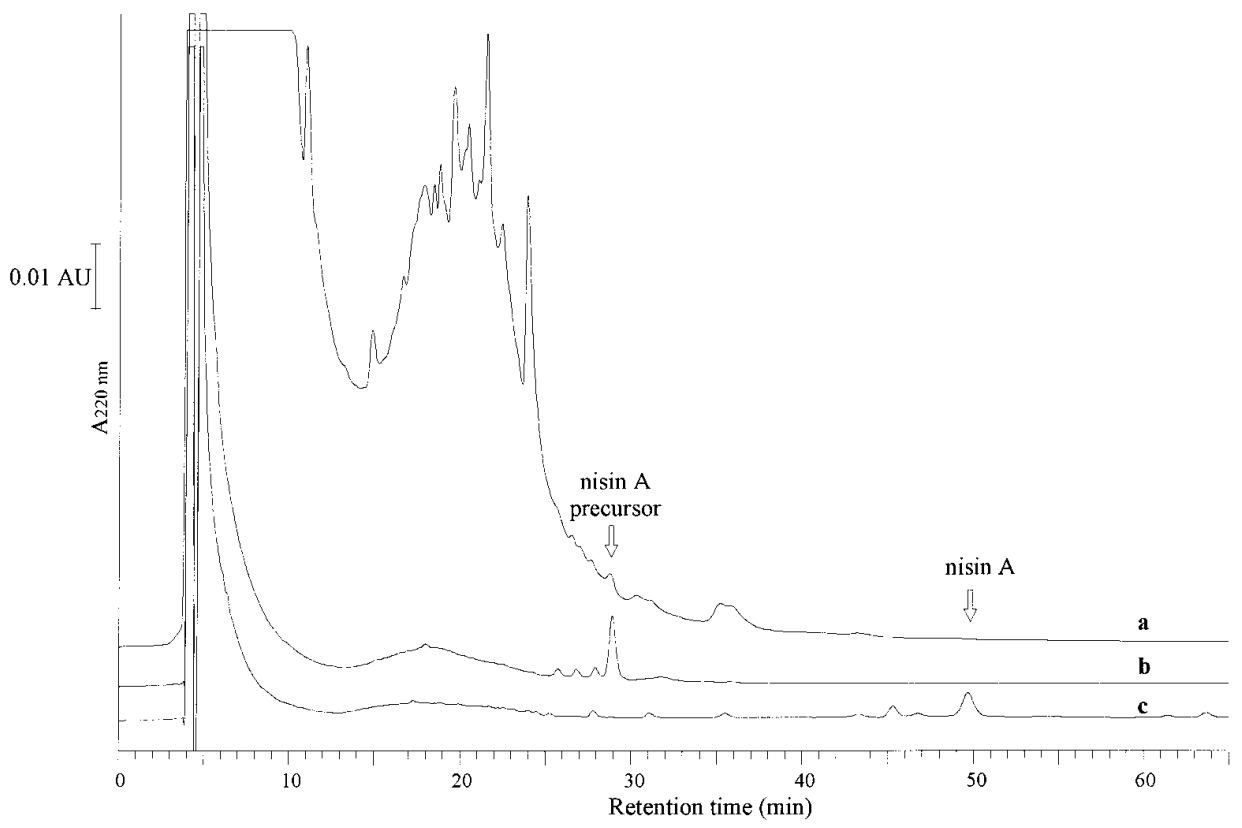

Figure 2. RP-HPLC chromatograms of (a) the undiluted cell-free extract (CFE) containing the nisin A precursor, (b) the $1 \mathrm{~mol} \cdot \mathrm{L}^{-1} \mathrm{KCl}$ fraction collected from the cation-exchange membrane after passing $3 \mathrm{~L}$ of the 10 -fold diluted CFE containing the nisin precursor, and (c) the $1 \mathrm{~mol} \cdot \mathrm{L}^{-1} \mathrm{KCl}$ fraction collected from the cation-exchange membrane after passing $3 \mathrm{~L}$ of 10 -fold diluted CFE containing the nisin precursor followed by 15 min hydrolysis with trypsin. For chromatographic conditions, see Section 2.3. Identification of nisin A and nisin A precursor was performed by mass spectrometry and by comparison with the elution behaviour of reference samples.

the bound protein was hydrolysed as described in Section 2.2. The membrane was first washed with $10 \mathrm{mmol} \cdot \mathrm{L}^{-1}$ ammonium hydrogen carbonate buffer acidified to $\mathrm{pH} 7.0$ with formic acid, and then with $7 \mathrm{~mol} \cdot \mathrm{L}^{-1}$ ammonia (pH ca. 12). Finally, it was treated with $1 \mathrm{~mol} \cdot \mathrm{L}^{-1} \mathrm{NaCl}$ in phosphate buffer. Monitoring the hydrolysis as a function of time by RP-HPLC analysis of the $\mathrm{NaCl}$ fractions revealed a progressive reduction in the size of the peak corresponding to caprine LF. After $4 \mathrm{~h}$ of hydrolysis on the membrane, the major component of the $\mathrm{NaCl}$ fraction corresponded to a peptide with molecular mass 22.878 , whereas after overnight hydrolysis the caprine LF molecule was completely fragmented into peptides and the major component corresponded to a peptide with mass
3493 (Figs. 3a and 3b). After desalting, the whole fraction shown in Figure 3 a had activity against $M$. flavus. The major component of this fraction showed a large inhibition halo when tested by the agar diffusion assay against $M$. flavus. The $\mathrm{N}$-terminal 10-residue sequence of this peptide with mass 3493 was PEWSK?YQWQ. The residue at position 6 could not be identified as it may correspond to the amino acid cysteine. Combining the measured molecular mass with the sequencing data of the peptide and matching these to the known sequence of caprine LF [8] indicated that this peptide corresponded to residues 14 to 42 of the sequence of mature caprine LF (theoretical mass 3494.1). Taken together, these results show that the antibacterial domain of caprine LF produced by peptic hydrolysis of this 

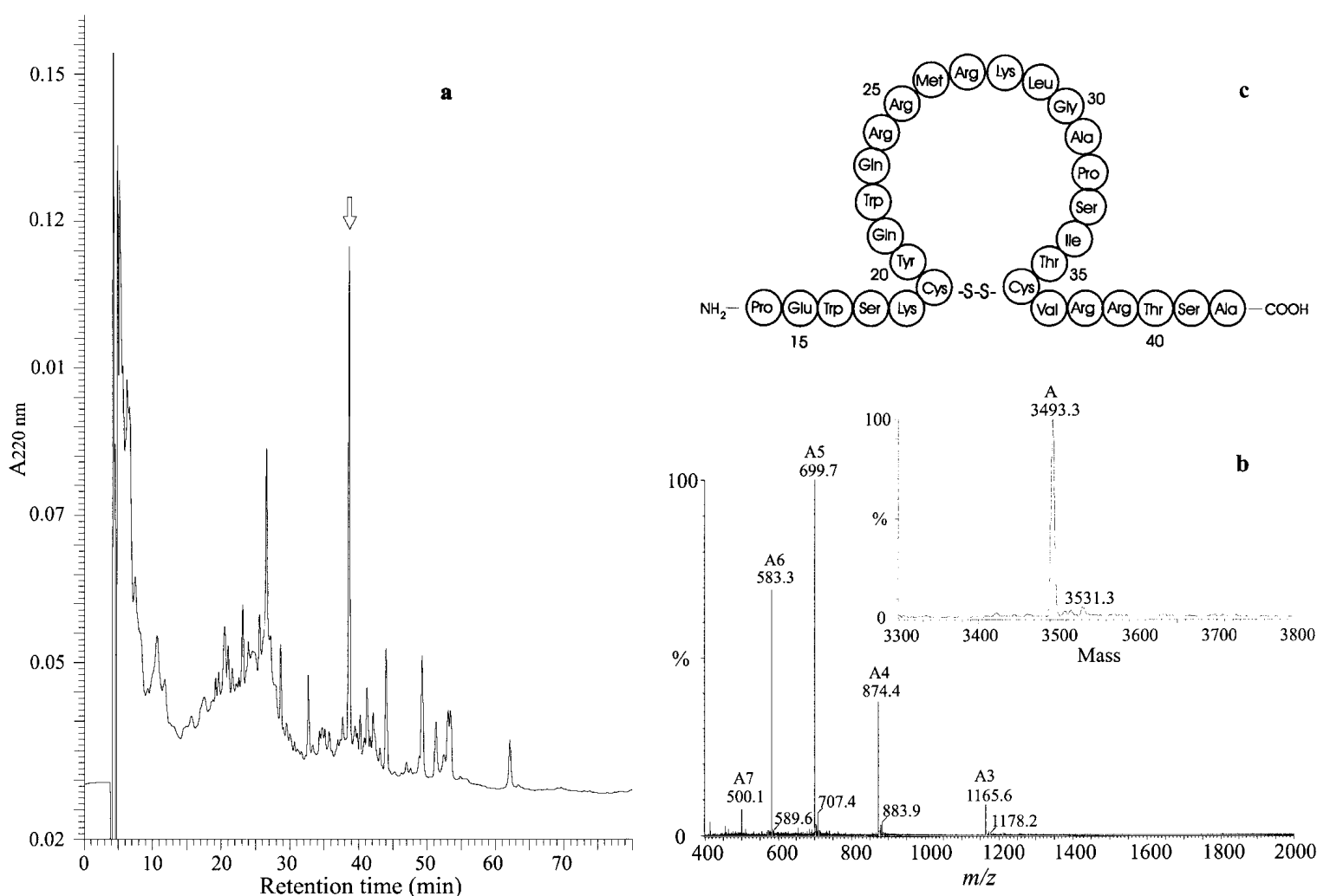

Figure 3. (a) RP-HPLC chromatogram of the $1 \mathrm{~mol} \cdot \mathrm{L}^{-1} \mathrm{NaCl}$ fraction collected from the cation-exchange membrane after passing ca. $1 \mathrm{~L}$ caprine cheese whey through the membrane followed by overnight hydrolysis of membrane-bound protein with pepsin. The arrow indicates the active component recovered for further purification. (b) Electrospray mass spectrum of the component marked with an arrow in Figure 3a. Ax denote components of the main envelope of multiply charged ions of the $\mathrm{m} / \mathrm{z}$ spectrum. The highest peak was set at $100 \%$. The inset represents the deconvoluted spectrum. (c) Schematic representation of the primary structure of the identified antibacterial domain of caprine LF. Numbers indicate positions in the sequence of mature caprine LF [8]. 
protein is a 29-residue peptide $\left(\mathrm{Pro}_{14}-\mathrm{Ala}_{42}\right)$ with 2 cysteines (positions 6 and 23) involved in the formation of an intrachain disulfide bridge (Fig. 3c). This peptide shows a high similarity (72\% sequence identity) to the bactericidal peptide isolated from bovine LF, lactoferricin-B, and may therefore be referred to as caprine lactoferricin or lactoferricin-C. Like lactoferricin-B, this peptide is located in the $\mathrm{N}$-terminal part of the LF molecule, is devoid of tyrosine or histidine, which are essential for the metalchelating functions of this protein, and contains several positively charged residues.

During the binding process, the identified domain of the caprine LF molecule seems to interact with the acidic groups of the cation-exchange membrane and it is retained after hydrolysis of the precursor protein while the other peptides are washed out. Therefore, the antimicrobial fragment of caprine LF might be exposed on the exterior of the folded LF molecule (as is the case in bovine LF [10]) and it seems to be responsible for the binding of the LF molecule to the chromatographic membrane. Further studies are required to determine quantitatively the antibacterial activity of this novel antibacterial peptide in comparison with the bactericidal peptide from bovine LF, lactoferricin-B. In addition, it remains to be determined whether these lactoferricins are produced during gastric digestion of LF in sufficient quantities to have any physiological significance.

\section{CONCLUSIONS}

Cationic antibacterial peptides are of interest in the food and non-food industry, because of their ability to inhibit pathogens and spoilage microorganisms. For practical use of these peptides as biopreservatives (e.g. in food), a fraction enriched in those peptides may be sufficient. However, a high yield, reproducibility and low cost will determine the choice for a specific purification protocol. This paper reports two new appli- cations of a successful strategy to produce cationic peptides from precursor polypeptides or proteins by in situ enzymatic cleavage of the precursor molecule bound to an ionic membrane. This method presents an obvious economic advantage: the isolation of the precursor is not necessary, since it is concentrated and subsequently hydrolysed within the separation medium. Therefore, the purification protocol, which classically would include three steps, i.e., isolation of the precursor protein, enzymatic hydrolysis of the precursor and isolation of the cationic peptide from the hydrolysate, is reduced to essentially one separation step to obtain a strongly enriched fraction.

\section{ACKNOWLEDGEMENTS}

The authors are grateful to C. van Kraaij and M. Beerthuyzen for providing the lactococcal strains and the reference samples of nisin and nisin precursor. The mass spectrometry facility used was funded by PPS MIBITON. I.R. acknowledges the European Commission for a scholarship.

\section{REFERENCES}

[1] Bellamy W., Takase M., Yamauchi K., Wakabayashi H., Kawase K., Tomita M., Identification of the bactericidal domain of lactoferrin, Biochim. Biophys. Acta 1121 (1992) 130-136.

[2] Boman H.G., Peptide antibiotics and their role in innate immunity, Annu. Rev. Immunol. 13 (1995) 61-92.

[3] Chiu C.K., Etzel M.R., Fractionation of lactoperoxidase and lactoferrin from bovine whey using a cation exchange membrane, J. Food Sci. 62 (1997) 996-1000.

[4] Dionysius D.A., Milne J.M., Antibacterial peptides of bovine lactoferrin: purification and characterization, J. Dairy Sci. 80 (1997) 667-674.

[5] Hancock R.E.W., Lehrer R., Cationic peptides: a new source of antibiotics, Trends Biotechnol. 16 (1998) 82-88.

[6] Hoek K.S., Milne J.M., Grieve P.A., Dionysius D.A., Smith R., Antibacterial activity of bovine lactoferrin-derived peptides, Antimicrob. Agents Chemother. 41 (1997) 54-59. 
[7] Kuipers O.P., Beerthuyzen M.M., Siezen R.J., De Vos W.M., Characterization of the nisin gene cluster nisABTCIPR of Lactococcus lactis. Requirement of expression of the nisA and nisI genes for development of immunity, Eur. J. Biochem. 216 (1993) 281-291.

[8] Le Provost F., Nocart M., Guérin G., Martin P., Characterization of the goat lactoferrin cDNA: Assignment of the relevant locus to bovine U12 synteny group, Biochem. Biophys. Res. Commun. 203 (1994) 1324-1332.

[9] Lee K.H., Hong S.Y., Oh J.E., Kwon M.Y., Yoon J.H., Lee J.H., Lee B.L., Moon H.M., Identification and characterization of the antimicrobial peptide corresponding to $\mathrm{C}$-terminal $\beta$-sheet domain of tenecin 1, an antibacterial protein of larvae of Tenebrio molitor, Biochem. J. 334 (1998) 99-105.

[10] Moore S.A., Anderson B.F., Groom C.R., Haridas M., Baker E.N., Three-dimensional structure of diferric bovine lactoferrin at $2.8 \mathrm{~A}$ resolution, J. Mol. Biol. 274 (1997) 222-236.

[11] Ooi Ch.E., Weiss J., Doerfler M.E., Elsbach P., Endotoxin-neutralizing properties of the $25 \mathrm{kD}$ $\mathrm{N}$-terminal fragment and a newly isolated $30 \mathrm{kD}$ C-terminal fragment of the 55-60 kD bactericidal/permeability-increasing protein of human neutrophils, J. Exp. Med. 174 (1991) 649-655.
[12] Recio I., Visser S., Two ion-exchange chromatographic methods for the isolation of antibacterial peptides from lactoferrin. In situ enzymatic hydrolysis on an ion-exchange membrane, J. Chromatogr. A 831 (1999) 191-201.

[13] Recio I., Visser S., Identification of two distinct antibacterial domains within the sequence of bovine $\alpha_{\mathrm{s} 2}$-casein, Biochim. Biophys. Acta 1428 (1999) $314-326$.

[14] van der Meer J.R., Polman J., Beerthuyzen M.M., Siezen R.J., Kuipers O.P., De Vos W.M., Characterization of the Lactococcus lactis nisin A operon genes nis $P$, encoding a subtilisin-like serine protease involved in precursor processing, and nisR, encoding a regulatory protein involved in nisin biosynthesis, J. Bacteriol. 175 (1993) 2578-2588.

[15] Yamauchi K., Tomita M., Giehl T.J., Ellison III R.T., Antibacterial activity of lactoferrin and pepsin-derived lactoferrin peptide fragment, Infect. Immun. 61 (1993) 719-728.

[16] Wakabayashi H., Bellamy W., Takase M., Tomita M., Inactivation of Listeria monocytogenes by lactoferricin, a potent antimicrobial peptide derived from cow's milk, J. Food Protect. 55 (1992) 238-240. 